\title{
Evaluation of Principal Partnership Programs in the Directorate of Education Management - The Application of Kirkpartick and Countenance Stake Evaluation Model
}

\author{
Wininng Widiharti", Burhanuddin Tola, Yetti Supriyat \\ Program Studi Penelitian dan Evaluasi Pendidikan, Universitas Negeri Jakarta, Indonesia
}

Received July 9, 2019; Revised September 9, 2019; Accepted September 16, 2019

Copyright $\bigcirc 2019$ by authors, all rights reserved. Authors agree that this article remains permanently open access under the terms of the Creative Commons Attribution License 4.0 International License

\begin{abstract}
This research aims to examine and explore the phenomenon of the principal's partnership program developed by the Directorate of Education Personnel in order to increase the professionalism of the school principal. The principal's partnership program is one of the most important and strategic programs in improving the quality of learning in schools, especially in the dimensions of learning, learning supervision, managerial and entrepreneurship as mandated in Permendiknas No. 13 of 2007 concerning competency standards of school principals. This study uses a combination of the "Kirckpatrick and Countenance Stake Evaluation Model" in evaluating the effectiveness of the principal's partnership program in 2018. The participants of the principal's partnership program involved were 295 people consisting of SD 130 school principals, SMP 60; SMA / SMK 89 and SLB 16. This study employs "mixed methods" that is the combination of quantitative and qualitative procedures in answering research questions. The results of the study show that from the antecedent aspect of the Model Countenance Stake, partnership programs are beneficial for improving the quality of school principals and equitable distribution of educational quality. The results of the study on level 1 of the Kirckpatrick model show participants' satisfaction with the implementation of partnership programs. At the level 2 learning, it has shown the effectiveness of partnership programs especially in increasing participants' knowledge in aspects of learning, managerial, supervision, and entrepreneurship. At Kirckpatrick's level 3, the behavioral dimension shows the level of discipline and skills in supervising learning at school. In the Kirckpatrick level 4 model, it shows a fairly good impact on the attitudes of teachers, students and the implementation of the 2013 curriculum and the development of RPP. Overall, the two
\end{abstract}

evaluation models, "Stake's Kirckpatrick and Countenance have found the benefits of the principal's partnership program results.

Keywords Partnership Program, Kirckpatrick, Countenance Stake, Principal, Evaluation

\section{Introduction}

The principal's partnership program has been developed and implemented by the Ministry of Education and Culture's Directorate (Kinanti, 2016) of Educational staff from 2015 to 2018 with various modifications programs according to the experience and results of the monitoring and evaluation that have been implemented so far (Waylen et al., 2019). Partnership programs among principals whose schools are more qualified and schools that are less qualified in various provinces, districts / cities in Indonesia, are developed to provide a medium for transformation of the quality culture between schools (Liu, 2018). However, the problem of disparity in the quality of schools between provinces, districts / cities within the province and between schools within districts / cities becomes the main challenge that needs to be addressed through the principal's partnership program (Seeley, Witbeck, \& Mulholland, 2018). School quality is one indicator of the principal's performance. This is in line with Permendiknas No. 13 of 2007 concerning Principal Competency Standards (NASIONAL, 2007) which include personality competencies, social competencies, managerial competencies and entrepreneurial competencies (van Dam, Schipper, \& Runhaar, 
2010) .The principal's partnership program is essential and strategic as an effort to minimize the quality culture gap between advanced and disadvantaged regional schools. This empirical question then encourages the importance of conducting research in this dissertation. The principal's partnership program is part of the effort to improve the distribution of education quality and school quality through (Kaplan, deBlois, Dominguez, \& Walsh, 2016) the top leadership of school organizations so that it can achieve a transformation of quality culture (Waylen et al., 2019) not only in schools but also in close partnership schools. Based on the consideration that the partnership program is a government program that has a noble goal to reduce the quality gap between schools, is widely implemented in various regions, has lasted several years, and there has never been a comprehensive research in this field; thus the authors are interested to focus her research on the principal's partnership program (Lau \& Ng, 2019), namely the exchange of good practices and mentoring from more qualified schools to less qualified schools.

\section{Literature Review}

\subsection{Research Question}

The research problems that need to be answered in this study are:

1. How is the descriptive description of various (Weiss-Cohen, Konstantinidis, Speekenbrink, \& Harvey, 2018) aspects of the principal's partnership program (the basic needs of the partnership program; the targeting of the partnership program; the selection of partnership participants; the facilitator, and the determination of the contents of the principal partnership program) to meet the principal's partnership program objectives?

2. How is the effectiveness of the principal's partnership program in terms of the dimensions of the Kirckpatrick Evaluation Model and the Countenance Stake model: Level 1 reaction (reaction); Level 2 (learning); Level 3 (Behavior); and level 4 results (outcomes)? (Kirkpatrick Partners, 2000)

\subsection{Principal Partnership}

The Ministry of Education and Culture partnership program which began in 2015 was carried out through (Roberts, 2018) the mechanism of exchanging partner principals with the impacted school principals and was named the Principal Leadership Comparative Study Program (Taylor, Goeke, Klein, Onore, \& Geist, 2011). And it has been designed at the 2015 In Service Learning-1 and On the Job Learning Workshop and at the same time identifying and analyzing the implementation of plans to improve the leadership quality of principals after the In Service Learning-1 Workshop. The impact generated by the intimate relationship between the school and the community(Cheng, Tung, Yang, \& Chiang, 2019) through the effectiveness of the principal's leadership appearance, are: (1) increasing the active participation of the community in educational activities(Kvartiuk, 2019); (2) improve communication between the school and the community; (3) schools can improve school education (Chen \& Feng, 2019)programs whose results are really needed by the community (link and match); and (4) the possibility of increased support from the community in the form of: funding, information and political support

\subsection{Industrial Revolution 4.0}

The American leadership method in the face of the Industrial Revolution (Nally \& Brooks, 2018) Industry 4.0 is considered a new industrial stage where the integration of vertical and horizontal manufacturing (Frank, Dalenogare, \& Ayala, 2019)processes and product connectivity can help companies to achieve higher industrial performance.(Dalenogare, Benitez, Ayala, \& Frank, 2018)

\section{Methodology/ Materials}

\subsection{Evaluation Model of Kirkpatrick and Stake}

This evaluation study uses a mixed model between the Evaluation Model by Kirkpatrick (2006) and the Countenance Model by Stake. Kirkpatrick's model is used to evaluate the implementation of training or In-Service Learning as well as Countenance Stake to evaluate the overall program. In this model, evaluation is carried out through four levels or stages, namely stages: 1) Reaction; this stage aims to determine the level of satisfaction of participants in the implementation of a training, 2) Learning; this stage aims to determine the level of change in knowledge, skills and changes in the attitude of participants after training, 3) behavior; this stage aims to determine the level of change in work behavior of trainees after returning to their work environment and 4) result is an evaluation to determine the impact of changes in the work behavior of trainees on the level of productivity of the organization or agency.

Countenance Stake's model, according to Fernandes, has two main things, namely: (1) description and (2) judgments, as well as distinguishing the existence of three stages in program evaluation, namely: (1) antecedent (context), (2) transactions (process), and (3) output (outcomes) (Worthen \& Sanders, 1973). Countenance Evaluation developed by Stake collects a series of information that is descriptive and contains elements of consideration from an object.

The use of Kirkpatrick's Model and Stake's Model in this study is showed in the following research design diagram. 


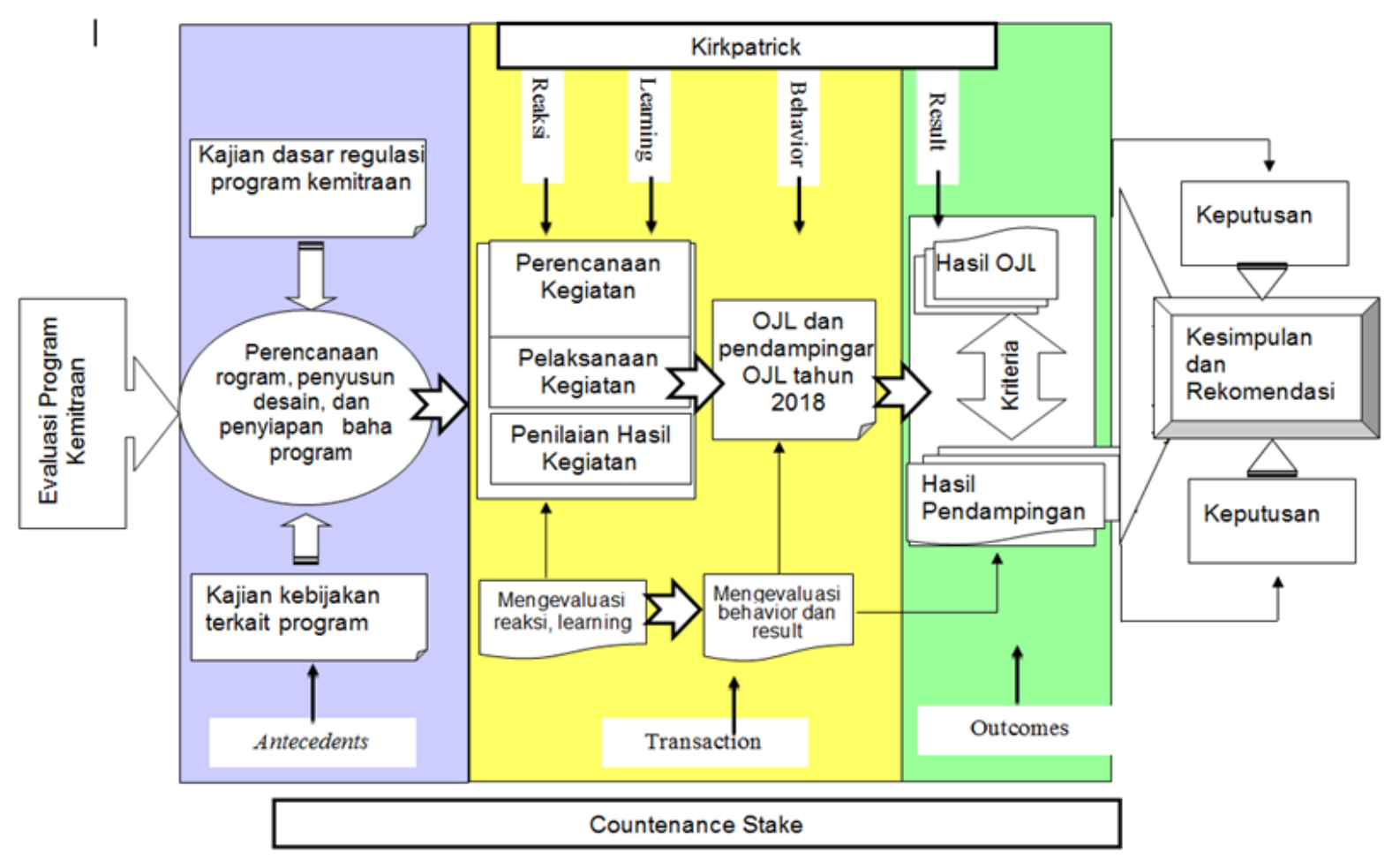

Figure 1. Research Design Quantitative and Qualitative Methods

This study uses a mixed approach that is the combination of quantitative and qualitative methods. Cresswell (2012) describes "a mixed methods research design as a procedure for collecting, analyzing, and" mixing " both the quantitative and qualitative studies of a series of studies to understand research problems" (Cresswell.W.John,2012). Furthermore, Cresswell.J.W (2002) states that "mixed methods" is a form of research design that is suitable for use when researchers intend to build the strength of both quantitative and qualitative data and complement in their analysis. This is supported by Miles and Huberman who stated that "when one combines quantitative and qualitative data, we have a very powerful mix" (Miles \& Huberman, 1994; Cresswell.J.W., 2012). By analyzing both the results of quantitative research and quality, complex and intact images can be developed from the phenomenon under study.

To answer the research question number one about how the antecedent aspect (context) of the principal's partnership program, it requires qualitative data in the form of documents and words of the interview results and analysis according to the qualitative approach. However, to examine how the effectiveness of the principal's partnership program in terms of the dimensions of the Kirckpatarick level 1, 2, 3 and 4 models used data and quantitative analysis such as descriptive statistics and t-test to test the increase in knowledge of the learning process results. In this context, of course, interview procedures, in-depth interviews and various documents can be clarified and deepened in understanding the interplay between phenomena.

According to Cresswell.W.J., (2012), there are generally four mixed methods designs: (1) the convergent parallel design; (2) the explanatory sequential design; (3) the exploratory sequential design and (4) the embedded design. In accordance with the four types of "mixed method" research designs, this dissertation employs "The Explanatory Sequential Design" because the researcher collects the data and analyzes the quantitative and qualitative data sequentially. Sequential stages are carried out by collecting data and quantitative analysis first and continuing with qualitative data collection and analysis. The design of the study using the "mixed methods" approach is described below.

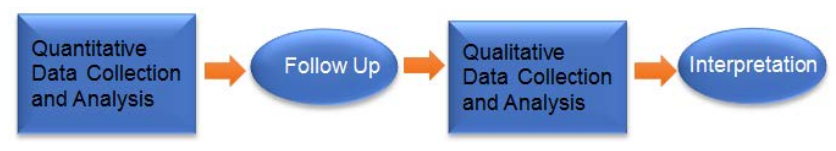

Figure 2. "Mixed Method” Explanatory Sequential Design

\subsection{Population and Samples}

The principal's partnership program in 2018 was attended by 495 school principals, consisting of 200 partner school principals who came from better quality schools and 295 affected school principals from poor schools in terms of its quality. The population of the study was the principal program held by the Directorate of Education Staff that there were about 295 affected school principals consisting of elementary school principals of 
130 people; Junior high school of 60 participants, and SMA / SMK of 89 participants and SLB of 16 participants.

The whole population of affected school principals was taken as a sample so that the total sample of this study was 295 principals. The whole schools come from several schools in the provinces which have the lowest national examinations in Indonesia established in the principal's partnership program.

\subsection{Data Collection Technique}

In answering research question particularly number one about the antecedent aspects of the principal's partnership program (Model Countenance Stake) which include sthe context of the basic needs of the partnership program, targeting partnership programs, selection of partnership principals, and the contents of the principal partnership program are carried out through:

Firstly, document Study Technique. Study procedures, document and policy studies are conducted to explore aspects of the partnership program development that cover policy background, targets to be achieved in partnership programs, basis for determining partnership program participants, mechanisms and procedures for implementing programs and the effectiveness of partnership programs in order to increase the professionalism of school principals .

Secondly, in-depth Interview Technique. That was conducted to explore more deeply and comprehensively of the document study so that it can produce more accurate views and various information or data obtained from the document review above. Interviews were conducted with stakeholders who are knowledgeable and involved directly or indirectly on partnership programs. Interviews were also conducted with decision-making officials and implementing program partners so as to obtain comprehensive information about the context of partnership policies and programs in order to improve the professionalism of school principals. The study of the context of the partnership program is an aspect that is emphasized in the Stake Countenance Model which is used as an evaluation model used in this dissertation.

Thirdly, Questionnaire Technique. That is to answer research question number two about the effectiveness of the principal's partnership program in terms of the "mixed Kirckpatrick model and Coutenance Stake model", and a questionnaire was used to measure the perceptions and impressions of participants in education and training on the implementation of the principal's partnership program as an indicator of the principal's partnership program effectiveness. Measurement of effectiveness according to the two models reflects the evaluation of the level 1 reaction (Kirckpatrick) of the principal program participant and the reaction is a manifestation of the process of interaction between participants, facilitators, services, facilities and environment during the partnership program.

Fourthly, Pre-test and Post-test Techniques. Learning dimensions obtained data from the results of pre-test and post-test for partnership material which included aspects of learning, managerial, academic supervision and entrepreneurship provided to participants of partnership programs consisting of elementary, junior high schools, vocational and high school principals. The learning dimension is level 2 in the Kirckpatrcik model which uses tests on the knowledge of participants in the four aspects of learning, managerial, supervision, and entrepreneurship which consists of 50 questions developed specifically for the principal's partnership program.

Lastly, Assessment and Observation Techniques. Data collection for the behavioral dimension which is Kirkpatrick's Model 3 level and the results of the interaction process in the Model Countenance Stake, and the results of observations and assessments of the disability behavior of principals during the partner and impact schools in the first and second periods were used. Furthermore, the behavioral dimension uses an assessment of the implementation of academic supervision obtained by participants in participating in the partnership program. The application of skills and knowledge in academic supervision is an indicator of change including disciplinary behavior as presented by the Kirckpatrick Level 3 model and the realization of the interaction of the learning process according to Stake's Model Countenance.

\section{Results and Findings}

In accordance with the research questions to be answered in this study, there are four variables used as a measure in assessing the effectiveness of education and training according to Kirkpatrick's Model (1998) as follows.

a. The reaction variable includes several indicators about participants' perceptions of the service of the organizing committee and its indicators; readiness of supporting facilities and indicators; readiness and suitability of teaching materials and indicators; learning atmosphere and indicators; and presentation of material by the facilitator and the indicators. Some of the indicators are set out in 5 Likert scale choices as stated in the questionnaire.

b. Learning variable is to determine the extent to which participants gain knowledge, improve their knowledge in the fields of learning, managerial, academic supervision and entrepreneurship. The principal partnership participants were given 50 tests that measured the mastery of the principal's knowledge in the fields of learning, managerial, academic supervision and entrepreneurship. Through the measurement of the pre-test and post-test, it was intended to determine the absorption of the knowledge of participants towards the four fields of knowledge.

c. Behavior variables are to determine how many partners in the principal program partnership have behavior changes after they return to their respective schools. Thus 
the behavioral dimension is more concerned with the question of how the principal's behavior in applying the knowledge and skills in their respective schools for the progress and development of the school. In this context the aspects of disciplinary behavior and indicators and the behavior of the application of learning supervision are indicators that are measured.

d. Result Variables are the overall results or impacts (outcomes) of the implementation of education and training programs. For the purposes of this study, the indicators measured are from various aspects of teachers' perceptions about curriculum 13, student interest, development of lesson plans, teacher professional skills in learning, and pedagogical abilities of teachers in learning.

Summary of the overall level 1 reaction (level) variables, level 2 aspects of learning (learning), level 3 about aspects of behavior (behavior) and level 4 about results (results) or the impact of the principal's partnership program, according to the Kirckpatrick and Antecedence models from the Countenance Model Stake is presented in the following variable, instrument and indicator.

Table ... Instruments

\begin{tabular}{|c|c|c|}
\hline Aspect & Indicator & Information \\
\hline $\begin{array}{l}\text { Planning/ Program } \\
\text { Design }\end{array}$ & $\begin{array}{l}\text { a) Program alignment with Government Nawacita } 2015-2019 \\
\text { b) Program alignment with the Ministry of Education } \\
\text { c) Suitability of the program with the target of the Ministry of Education's strategic plan }\end{array}$ & Antecedents \\
\hline Workshop Planning & $\begin{array}{l}\text { a) Suitability of the workshop program with participants' learning needs } \\
\text { b) Suitability of the workshop program with the participants' learning abilities } \\
\text { c) Conformity of the workshop program with previous experience } \\
\text { d) The suitability of the workshop program with the participants' expectations towards the } \\
\text { joined training program } \\
\text { e) Suitability of the workshop program with new knowledge and gained experience } \\
\text { f) Workshop needs analysis and review of program design are carried out }\end{array}$ & Antecedents \\
\hline $\begin{array}{l}\text { Workshop } \\
\text { Preparation }\end{array}$ & $\begin{array}{l}\text { a) The process of recruiting participants } \\
\text { b) Registration and accommodation services } \\
\text { c) Clarity of discipline and training objectives } \\
\text { d) Letter of summons for participants } \\
\text { e) Clarity of criteria and administrative advantages that are needed } \\
\text { f) Schedule and plan program activities. }\end{array}$ & Antecedents \\
\hline $\begin{array}{l}\text { Lesson (Learning } \\
\text { Plan) }\end{array}$ & $\begin{array}{l}\text { a) Suitability of program structure and schedule of activities } \\
\text { b) Readiness of syllabus and learning plan }\end{array}$ & Antecedents \\
\hline Committee Services & $\begin{array}{l}\text { a) ATK services } \\
\text { b) Attendance and Journal Services } \\
\text { c) Photocopy service. } \\
\text { d) Services of providing workshop materials } \\
\text { e) Refreshments }\end{array}$ & Level 1: Reaction \\
\hline $\begin{array}{c}\text { Cleanliness and } \\
\text { comfort of workshop } \\
\text { facilities }\end{array}$ & $\begin{array}{l}\text { a) Cleanliness of the learning environment } \\
\text { b) Cleanliness of bathrooms and toilets } \\
\text { c) Cleanliness and comfort of the dining room } \\
\text { d) Cleanliness and comfort of the hostel } \\
\text { e) Cleanliness and comfort of classrooms }\end{array}$ & Level 1: Reaction \\
\hline $\begin{array}{l}\text { Readiness of } \\
\text { supporting facilities }\end{array}$ & $\begin{array}{l}\text { a) Availability of internet networks } \\
\text { b) Readiness of library facilities } \\
\text { c) Readiness of classrooms, study rooms, discussion rooms } \\
\text { d) Availability of adequate lighting } \\
\text { e) Availability of places for worship } \\
\text { f) Availability of sports facilities } \\
\text { g) Convenience and security of the environment of the activity site }\end{array}$ & Level 1: Reaction \\
\hline $\begin{array}{c}\text { Readiness and } \\
\text { suitability of teaching } \\
\text { materials }\end{array}$ & $\begin{array}{l}\text { a) Practicality of teaching materials } \\
\text { b) Readability of teaching materials } \\
\text { c) Ease of access to teaching materials } \\
\text { d) Suitability of teaching materials with the workshop } \\
\text { e) The relevance of teaching materials to the needs of participants in implementing the } \\
\text { OJL }\end{array}$ & Level 1: Reaction \\
\hline $\begin{array}{l}\text { Readiness and } \\
\text { suitability of teaching } \\
\text { materials }\end{array}$ & $\begin{array}{l}\text { a) Suitability of teaching materials with the delivered material } \\
\text { b) Complete coverage of teaching materials content }\end{array}$ & Level 1: Reaction \\
\hline Learning Atmosphere & $\begin{array}{l}\text { a) The approach used } \\
\text { b) The portion of the task load from the facilitator } \\
\text { c) Appreciation of the opinions of participants } \\
\text { d) Empathy of facilitators to participants } \\
\text { e) Similarity in treatment } \\
\text { f) Alignment in the learning process }\end{array}$ & Level 1: Reaction \\
\hline
\end{tabular}




\begin{tabular}{|c|c|c|}
\hline Aspect & Indicator & Information \\
\hline $\begin{array}{l}\text { Material presentation } \\
\text { by the facilitator }\end{array}$ & $\begin{array}{l}\text { a) Mastery of material } \\
\text { b) Application of learning methods } \\
\text { c) Systematic presentation } \\
\text { d) Ability to respond to participants' questions } \\
\text { e) Tools and media utility } \\
\text { f) Language Usage } \\
\text { g) The ability to build interaction in learning } \\
\text { h) Consistency between the presentation of material and the learning scenario } \\
\text { i) Use of time } \\
\text { j) Participation of participants in learning }\end{array}$ & Level 1: Reaction \\
\hline $\begin{array}{l}\text { Attitude and Behavior } \\
\text { of facilitators in the } \\
\text { workshop process }\end{array}$ & $\begin{array}{l}\text { a) Openness } \\
\text { b) Hospitality } \\
\text { c) Respect for participants } \\
\text { d) Self control } \\
\text { e) Appearance } \\
\text { f) Cooperation }\end{array}$ & $\begin{array}{l}\text { Level 1: } \\
\text { Reaction }\end{array}$ \\
\hline $\begin{array}{l}\text { Knowledge of the } \\
\text { principal }\end{array}$ & $\begin{array}{l}\text { a) Learning } \\
\text { b) Managerial } \\
\text { c) Learning Supervision } \\
\text { d) Entrepreneurship }\end{array}$ & Level 2: Learning \\
\hline Discipline behavior & $\begin{array}{l}\text { a) Discipline at the time of the OJL } \\
\text { b) Discipline attitude during mentoring Phase } 1 \\
\text { c) Discipline attitude during mentoring Phase } 2\end{array}$ & Level 3: Behavior \\
\hline $\begin{array}{l}\text { Implementation } \\
\text { results (Supervision } \\
\text { of learning) }\end{array}$ & $\begin{array}{l}\text { a) Preparation of an academic supervision program } \\
\text { b)Organizing the implementation of academic supervision tasks } \\
\text { c) Preparation of supervision instruments } \\
\text { d) Implementation of supervision } \\
\text { e)Evaluating the implementation of academic supervision }\end{array}$ & Level 3: Behavior \\
\hline $\begin{array}{l}\text { Implementation } \\
\text { results (curriculum } \\
\text { management) }\end{array}$ & $\begin{array}{l}\text { Short-Term Impact } \\
\text { a) Impact of teacher perceptions on k13 } \\
\text { b) Specialization of students } \\
\text { c) RPP development } \\
\text { d) Professional skills of teachers in learning } \\
\text { e) Teacher's pedagogical ability in learning } \\
\text { Long-term Impact } \\
\text { a) Discipline of teachers and students in the class } \\
\text { b) Academic and non-academic achievements }\end{array}$ & $\begin{array}{l}\text { Level 4: Result/ } \\
\text { Impact }\end{array}$ \\
\hline
\end{tabular}

Information:

K1 = Questionnaire 1 (for principals participating in the program)

$\mathrm{K} 2$ = Questionnaire 2 (for teachers from the program participating schools

$\mathrm{W}=$ Interview Guidelines

$\mathrm{D}=$ Document Analysis Guidelines

$\mathrm{O}=$ Observation Guidelines

\section{Data Analysis}

Analysis of data to answer research questions about reactions as variables or dimensions of training effectiveness, descriptive statistical analysis was employed. Meanwhile, data analysis to answer research questions about learning variables employs the Non Parametric Statistical Test, the Wilcoxon Test. To answer the research question about the variable or behavioral dimension (descriptive behavior), descriptive statistical analysis is used in the form of a percentage or frequency of distribution that describes aspects of discipline and the behavior of the implementation of academic supervision carried out by the principals in each school environment. Furthermore, to answer the research questions about the results variable, statistical descriptive techniques are used in the form of distribution frequency and on average to find out the impact of the partnership program on teachers, students and the atmosphere of learning in the schools of each principal participating in the partnership program.

\section{Conclusions}

Program evaluation at any time is seen as a process that is held independently when the program is established and has been operated so that it can make an improvement, increase accountability, and a deeper understanding of the phenomenon.

\section{Acknowledgements}

Ministry of Education and Culture of the Republic of 
Indonesia.

Sulfikar Sallu ID Scopus 57200989289 mahasiswa S3 Teknologi Pendidikan Universitas Negeri Jakarta dan Dosen Fakultas Teknologi Informasi Unbiversitas Sembilan belas November Kolaka.

\section{REFERENCES}

[1] Chen, Y., \& Feng, S. (2019). The education of migrant children in China's urban public elementary schools: Evidence from Shanghai. China Economic Review, 54, 390-402. doi:10.1016/j.chieco.2019.02.002

[2] Cheng, Y.-Y., Tung, W.-F., Yang, M.-H., \& Chiang, C.-T. (2019). Linking relationship equity to brand resonance in a social networking brand community. Electronic Commerce Research and Applications, 35, 100849. doi:10.1016/j.elerap.2019.100849

[3] Dalenogare, L. S., Benitez, G. B., Ayala, N. F., \& Frank, A. G. (2018). The expected contribution of Industry 4.0 technologies for industrial performance. International Journal of Production Economics, 204, 383-394. doi:10.1016/j.ijpe.2018.08.019

[4] Frank, A. G., Dalenogare, L. S., \& Ayala, N. F. (2019). Industry 4.0 technologies: Implementation patterns in manufacturing companies. International Journal of Production Economics, 210, 15-26. doi:10.1016/j.ijpe.2019.01.004

[5] Kaplan, D. M., deBlois, M., Dominguez, V., \& Walsh, M. E. (2016). Studying the teaching of kindness: A conceptual model for evaluating kindness education programs in schools. Eval Program Plann, 58, 160-170. doi:10.1016/j.evalprogplan.2016.06.001

[6] Kinanti, Y. C. (2016). KEMITRAAN SEKOLAH DALAM MENINGKATKAN MUTU PENDIDIKAN DI SMA NEGERI 2 YOGYAKARTA. 175.

[7] Kirkpatrick Partners. (2000). The Kirkpatrick Model.

[8] Kvartiuk, V. (2019). Trust, mental models and community participation in transition: Evidence from rural Ukraine. Communist and Post-Communist Studies. doi:10.1016/j.postcomstud.2019.04.003

[9] Lau, E. Y. H., \& Ng, M. L. (2019). Are they ready for home-school partnership? Perspectives of kindergarten principals, teachers and parents. Children and Youth Services Review, 99, 10-17. doi:10.1016/j.childyouth.2019.01.019

[10] Liu, J. (2018). Constructing resource sharing collaboration for quality public education in urban China: Case study of school alliance in Beijing. International Journal of Educational Development, 59, 9-19. doi:10.1016/j.ijedudev.2017.09.004

[11] Nally, D., \& Brooks, C. (2018). From the Teen to the Green Revolution: American philanthropy and youth club work in Northern Europe. Journal of Historical Geography, 61, 27-43. doi:10.1016/j.jhg.2018.03.002
[12] NASIONAL, M. P. (2007). PERATURAN MENTERI PENDIDIKAN NASIONAL.

[13] Roberts, K. J. (2018). Community engagement in Indian higher education: Financial and partnership trends. International Journal of Educational Development, 58, 95-105. doi:10.1016/j.ijedudev.2017.03.005

[14] Seeley, R. J., Witbeck, G., \& Mulholland, M. W. (2018). Expanding industry partnerships through an accelerated business engagement program. Surgery. doi:10.1016/j.surg.2018.03.015

[15] Taylor, M., Goeke, J., Klein, E., Onore, C., \& Geist, K. (2011). Changing leadership: Teachers lead the way for schools that learn. Teaching and Teacher Education, 27(5), 920-929. doi:10.1016/j.tate.2011.03.003

[16] van Dam, K., Schipper, M., \& Runhaar, P. (2010). Developing a competency-based framework for teachers' entrepreneurial behaviour. Teaching and Teacher Education, 26(4), 965-971. doi:10.1016/j.tate.2009.10.038

[17] Waylen, K. A., Blackstock, K. L., van Hulst, F. J., Damian, C., Horvath, F., Johnson, R. K., . . . Van Uytvanck, J. (2019). Policy-driven monitoring and evaluation: Does it support adaptive management of socio-ecological systems? Sci Total Environ, 662, 373-384. doi:10.1016/j.scitotenv.2018.12.462

[18] Weiss-Cohen, L., Konstantinidis, E., Speekenbrink, M., \& Harvey, N. (2018). Task complexity moderates the influence of descriptions in decisions from experience. Cognition, 170, 209-227. doi:10.1016/j.cognition.2017.10.005 